\title{
Meiotic abnormalities affect genetic constitution and pollen viability in dicots from Indian cold deserts
}

\author{
Dalvir Kaur ${ }^{1 *}$ and V. K. Singhal ${ }^{2}$
}

\begin{abstract}
Background: Meiotic abnormalities lead to morphological and genetic variations which caused not only to evolution but also intraspecific reproductive barriers. During present study of detailed meiotic course in dicotyledonous plants sampled from Indian cold deserts, various meiotic abnormalities have been detected. For this, the plant materials fixed in Carnoy's fixative and studied detailed meiotic course by standard squash method in 1\% acetocarmine.

Results: Meiotic abnormalities have been presently detected in 71 species which include multiple associations in diploids (Achillea millefolium L.), multivalents and univalents in polyploids (4 species), cytomixis (40 species), chromosome stickiness (20 species), nonsynchronous disjunction of bivalents (32 species), interbivalent connections (15 species), synaptic mutants (2 species), syncyte meiocytes (2 species), abnormal spindles (7 species), and fusion of pollen grains (1 species), laggards and chromatin bridges, hypo-, hyperploid PMCs, monads, dyads, triads, tetrads with micronuclei and polyads.

Conclusions: Consequently, variable sized apparently fertile pollen grains and considerable amount of sterile pollen grains are resulted as end products which lead to different genetic constitution (aneuploids and polyploids) and curtailed sexual reproductive success in these species.
\end{abstract}

Keywords: Meiosis, Meiotic abnormalities, Pollen grains, Aneuploids, Polyploids, Sexual reproduction

\section{Background}

Meiosis, [1] a critical process has a key role in the reproduction and life cycle of flowering plants involves homologous chromosomes pair, synapsis, recombination and segregation that reduces the chromosome number by half and ensures the operation of Mendel's law of heredity [2]. The normal and harmonious course of meiosis in pollen mother cells including regular bivalent formation and normal cytokinesis ensures $100 \%$ pollen viability [3]. Any abnormality in course of meiosis causes the formation of sterile gametes and low percentage of pollen viability [4]. An array of genes is known to involve in each and every step of meiotic process [3, 5-7]. Further alongwith genic factors, various environmental factors determine the harmony of this process [8]. To investigate the evolutionary trends occurring in the species, a detailed meiotic

\footnotetext{
* Correspondence: dalvircyto@gmail.com

'Department of Botany, Patel Memorial National College, Rajpura affiliated to

Punjabi University, Patiala, Punjab, India

Full list of author information is available at the end of the article
}

analysis could be a strong parameter which includes the nature of chromosomes pairing, chromosome behaviour during segregation and microsporad formation [9]. Formation of genetically different gametes due to abnormal meiotic processes could lead to effective reproductive barriers between the species [10]. During the evaluation of meiotic behavior in the dicot plants sampled from Kinnaur district of Himachal Pradesh (India) which is known for its rugged mountains, cold deserts, high altitudes, harsh climatic conditions and remote district in India, 71 species showed various meiotic abnormalities which curtailed the considerable amount of pollen fertility and led to the production of heterogeneous sized fertile pollen grains.

\section{Results}

In our present studies total 71 taxa (22 polyploids and 49 diploids) showed abnormal meiotic abnormalities (Table 1) which include chromosomal multiple associations in diploids and polyploids, chromatin stickiness, deviant pairing 
Table 1 A list of cytologically investigated species with locality, accession number, meiotic chromosome number, meiotic abnormalities and pollen grains

\begin{tabular}{|c|c|c|c|c|c|c|c|c|c|c|c|c|c|c|c|c|}
\hline & \multirow[t]{2}{*}{ Taxon } & \multirow{2}{*}{$\begin{array}{l}\text { Locality (altitude } \\
\text { in metre) }\end{array}$} & \multirow{2}{*}{$\begin{array}{l}\text { Accession } \\
\text { number } \\
\left(P \cup N^{a}\right)\end{array}$} & \multirow{2}{*}{$\begin{array}{l}\text { MCN } \\
\text { (Ploidy } \\
\text { level) }\end{array}$} & \multicolumn{9}{|c|}{ Meiotic irregularities } & \multicolumn{3}{|c|}{ Pollen grains } \\
\hline & & & & & $\mathrm{C}$ & CS & $U$ & M & AM & ND & $L$ & $\mathrm{CB}$ & $\mathrm{AbM}$ & PS & HSPG & FPG \\
\hline \multirow[t]{2}{*}{1.} & FAMILY: RANUNCULACEAE & & & & & & & & & & & & & & & \\
\hline & Anemone rivularis Buch.-Ham. ex DC. & Kalpa, 2760 & 50898 & $8(2 x)$ & + & + & - & - & - & - & + & + & + & + & + & - \\
\hline 2. & Aquilegia fragrans Benth. & Chittkul, 3450 & 53994 & $7(2 x)$ & + & - & - & - & - & - & - & - & - & - & - & - \\
\hline 3. & Clematis grata Wall. & Bhabnagar, 1900 & 50905 & $8(2 x)$ & + & + & - & - & - & - & + & + & + & + & - & - \\
\hline 4. & C. graveolens Lindl. & Thangi, 2700 & 53858 & $8(2 x)$ & + & + & - & - & - & + & + & + & + & + & + & + \\
\hline 5. & C. orientalis L. var. acutifolia Hook. f. et Thoms. & Nako, 3660 & 49994 & $16(4 x)$ & + & + & - & - & - & + & + & + & + & + & + & - \\
\hline 6. & Delphinium roylei Munz & Sangla, 2680 & 53998 & $8(2 x)$ & - & - & - & - & - & + & - & - & - & - & - & - \\
\hline 7. & Ranunculus laetus Wall. ex Royle & Sangla, 2680 & 50946 & $14(4 x)$ & + & + & - & - & - & + & + & + & + & + & + & - \\
\hline 8. & R. sceleratus L. & Nichar, 2150 & 54006 & $16(4 x)$ & - & + & - & - & - & + & + & + & + & + & + & - \\
\hline 9. & Thalictrum cultratum Wall. & Nichar, 2150 & 53847 & $21(4 x)$ & + & - & - & - & - & + & + & + & + & + & + & - \\
\hline 10. & T. foetidum L. & Sangla, 2680 & 50947 & $21(6 x)$ & + & - & - & - & - & - & + & + & + & + & + & - \\
\hline 11. & T. minus $\mathrm{L}$. & Chittkul, 3450 & 53887 & $7(2 x)$ & + & - & - & - & - & - & - & - & - & - & - & - \\
\hline \multirow[t]{2}{*}{12.} & - FAMILY: BERBERIDACEAE & & & & & & & & & & & & & & & \\
\hline & Berberis kunwarensis Royle & Sangla, 2680 & 54025 & $14(2 x)$ & - & + & - & - & - & + & - & + & - & - & - & - \\
\hline \multirow[t]{2}{*}{13.} & FAMILY: PAPAVERACEAE & & & & & & & & & & & & & & & \\
\hline & Papaver dubium L. & Sangla, 2680 & 50952 & $14(4 x)$ & - & - & - & - & - & + & + & + & + & + & + & - \\
\hline \multirow[t]{2}{*}{14.} & FAMILY: CARYOPHYLLACEAE & & & & & & & & & & & & & & & \\
\hline & Dianthus angulatus Royle ex Benth. & Sangla, 2680 & 50486 & $15(2 x)$ & + & - & + & - & + & - & + & - & + & + & + & - \\
\hline 15. & Myosoton aquaticum (L.) Moench & Nichar, 2150 & 53734 & $14(2 x)$ & - & + & - & - & - & - & - & - & - & - & - & - \\
\hline 16. & Silene edgeworthii Bocquet & Sangla, 2680 & 50961 & $12(2 x)$ & + & - & - & - & - & - & - & - & + & + & + & - \\
\hline 17. & Spergularia diandra (Guss.) Heldr. \& Sart. & Chango, 3050 & 53741 & $18(4 x)$ & + & + & - & - & - & - & + & - & + & + & + & - \\
\hline \multirow[t]{2}{*}{18.} & FAMILY GERANIACEAE & & & & & & & & & & & & & & & \\
\hline & Geranium pratense L. & Chittkul, 3450 & 50924 & $28(4 x)$ & - & + & - & + & - & - & - & - & + & + & + & - \\
\hline \multirow[t]{2}{*}{19.} & FAMILY: BALSAMINACEAE & & & & & & & & & & & & & & & \\
\hline & Impatiens brachycentra Kar. et Kir. & $\begin{array}{l}\text { Reckong Peo, } \\
2670\end{array}$ & 50888 & $7(2 x)$ & - & - & - & - & - & + & - & - & - & - & - & - \\
\hline \multirow[t]{2}{*}{20.} & FAMILY: PAPILIONACEAE & & & & & & & & & & & & & & & \\
\hline & Astragalus grahamianus Royle ex Benth. & Rakchham, 3115 & 53673 & $8(2 x)$ & + & - & - & - & - & - & + & - & + & + & - & - \\
\hline 21. & A. graveolens Buch.-Ham. ex Benth. & Sangla, 2680 & 50900 & $8(2 x)$ & + & + & - & - & - & - & + & + & + & + & + & - \\
\hline 22. & - Colutea nepalensis Sims & Khab, 2800 & 53684 & $8(2 x)$ & - & - & - & - & - & - & + & & + & + & - & - \\
\hline 23. & - Indigofera heterantha Wall. ex Brandis & Rakchham, 3115 & 50912 & $24(6 x)$ & + & - & - & - & - & - & - & - & - & + & - & - \\
\hline 24. & - Lotus corniculatus L. & Chitkul, 3450 & 53690 & $6(2 x)$ & + & - & - & - & - & - & + & + & + & + & - & - \\
\hline 25. & - Medicago falcata L. & Thangi, 2700 & 53695 & $8(2 x)$ & + & - & - & - & - & - & - & - & + & + & - & - \\
\hline 26. & Melilotus alba Lamk. & Thangi, 2700 & 53699 & $8(2 x)$ & + & - & - & - & - & - & - & - & + & + & - & - \\
\hline 27. & Trifolium repens $\mathrm{L}$. & Sangla, 2680 & 50916 & $16(4 x)$ & + & - & - & - & - & - & - & - & + & + & - & - \\
\hline 28. & Trigonella emodi Benth. & Chitkul, 3450 & 53713 & $8(2 x)$ & + & - & - & - & - & - & - & - & + & + & + & - \\
\hline 29. & T. pubescens Edgew. ex Baker & Rakchham, 3115 & 53716 & $8(2 x)$ & + & - & - & - & - & + & + & + & + & + & + & - \\
\hline 30. & Vicia pallida Turcz. & Palingi, 1900 & 53708 & $12(4 x)$ & + & + & - & - & - & + & + & + & + & + & + & - \\
\hline 31. & - V. rigidula Royle & Kalpa, 2760 & 50919 & $12(4 x)$ & + & + & - & - & - & + & + & + & + & + & + & - \\
\hline 32. & - V. sativa $\mathrm{L}$. & Kuppa, 2600 & 53709 & $6(2 x)$ & - & - & - & - & - & + & - & + & - & - & - & - \\
\hline 33. & V. tenera Grah. & Sangla, 2680 & 51952 & $7(2 x)$ & - & - & - & - & - & + & + & + & + & + & - & - \\
\hline
\end{tabular}


Table 1 A list of cytologically investigated species with locality, accession number, meiotic chromosome number, meiotic abnormalities and pollen grains (Continued)

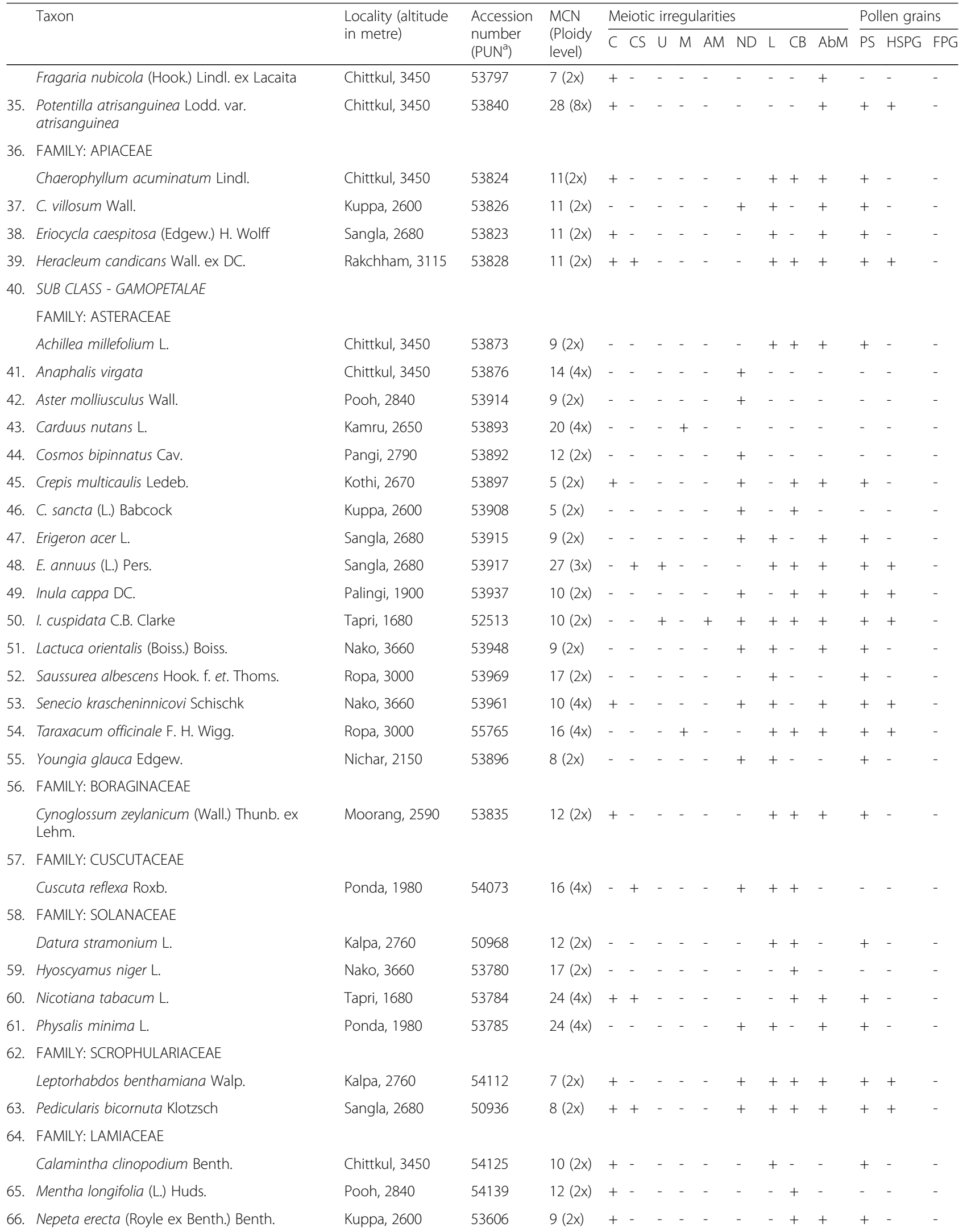


Table 1 A list of cytologically investigated species with locality, accession number, meiotic chromosome number, meiotic abnormalities and pollen grains (Continued)

\begin{tabular}{|c|c|c|c|c|c|c|c|c|c|c|c|c|c|c|c|c|}
\hline & \multirow[t]{2}{*}{ Taxon } & \multirow{2}{*}{$\begin{array}{l}\text { Locality (altitude } \\
\text { in metre) }\end{array}$} & \multirow{2}{*}{$\begin{array}{l}\text { Accession } \\
\text { number } \\
\left(P \cup N^{a}\right)\end{array}$} & \multirow{2}{*}{$\begin{array}{l}\text { MCN } \\
\text { (Ploidy } \\
\text { level) }\end{array}$} & \multicolumn{9}{|c|}{ Meiotic irregularities } & \multicolumn{3}{|c|}{ Pollen grains } \\
\hline & & & & & $\bar{C}$ & CS & $U$ & $M$ & AM & ND & $L$ & $C B$ & $\overline{\mathrm{AbM}}$ & $\overline{P S}$ & HSPG & $\mathrm{FPG}$ \\
\hline 67. & Salvia nubicola Wall. ex Sweet & Sangla, 2680 & 50930 & $8(2 x)$ & + & - & - & - & - & + & + & + & + & + & - & - \\
\hline 68. & Thymus linearis Benth. & Kuppa, 2600 & 53631 & $13(2 x)$ & + & - & - & - & - & - & + & - & + & + & + & - \\
\hline \multirow[t]{3}{*}{69.} & SUB CLASS - MONOCHLAMYDAE & & & & & & & & & & & & & & & \\
\hline & FAMILY: PHYTOLACCACEAE & & & & & & & & & & & & & & & \\
\hline & Phytolacca acinosa Roxb. & Sangla, 2680 & 54074 & $36(8 x)$ & - & - & - & - & - & - & + & + & - & + & - & - \\
\hline 70. & $\begin{array}{l}\text { FAMILY: POLYGONACEAE Rumex hastatus D. } \\
\text { Don }\end{array}$ & Kothi, 2670 & 50895 & $9(2 x)$ & - & - & - & - & - & - & - & + & - & - & - & - \\
\hline \multirow[t]{2}{*}{71.} & FAMILY: ELAEAGNACEAE & & & & & & & & & & & & & & & \\
\hline & Hippophae rhamnoides L. & Kalpa, 2760 & 49377 & $9(2 x)$ & + & + & - & - & - & + & + & + & + & + & + & - \\
\hline
\end{tabular}

Symbol + (presence) and - (absence) of meiotic irregularities

a Code of Herbarium maintained by the Department of Botany, Punjabi University, Patiala, India as per "Index Herbariorum" by Holmgren and Holmgren (1998) MCN Meiotic Chromosome Number; C Cytomixis; CS Chromosome Stickiness; U Univalents; M Multivalents; AM Asynaptic Mutant; ND Nonsynchronous Disjunction; L Laggard; CB Chromatin Bridge; AbM Abnormal Microspore; PS Pollen Sterility; HSPG Heterogenous Sized Pollen Grains; FPG Fused Pollen Grains

and disjunction of bivalents, cytomixis, amalgamated meiocytes, abnormal spindle, laggards and chromatin bridges, anomalous sporads, and united pollen grains. Inconstant sized fertile gametes and significant pollen sterility are the final outcome of all these abnormalities in this present study.

\section{Chromosomal multiple association in diploids}

Among the 49 diploid taxa, Achillea millefolium L. ( $n=9$; $2 \mathrm{x}$ ) have been noticed for the first time with chromosomal multiple associations which is collected from Chittkul region of Kinnaur district at the altitude of $3450 \mathrm{~m}$. In this species chromosomes were involved in the formation of chain, zigzag and ring type quadrivalents (Fig. 1a, b). These multivalents showed delayed segregation as comparative to normal bivalents during anaphases which become the cause of abnormal microspore formation and low pollen fertility.

\section{Chromosomal multiple association in polyploids}

Four polyploids named Erigeron annuus (L.) Pers. $(2 \mathrm{n}=27 ; 3 \mathrm{x})$ (Fig. 1c), Carduus nutans L. $(2 \mathrm{n}=40 ; 4 \mathrm{x})$ (Fig. 1d, e), Geranium pratense L. $(2 \mathrm{n}=56 ; 4 \mathrm{x})$ (Fig. 1f), and Taraxacum officinale F. H. Wigg. $(2 \mathrm{n}=32 ; 4 \mathrm{x})$ (Fig. 1g, h) detected to be imbalanced polyploids having irregular pattern of pairing of chromosomes. The analysis of variable frequency of multivalents and univalents provide the knowledge about the nature of polyploidy. In Erigeron annuus, the presence of high frequency of unpaired chromosomes specified the allopolyploid nature of studied taxa. Presence of some multivalents in Carduus nutans (4x), Geranium pratense (4x) and Taraxacum officinale $(4 \mathrm{x})$ indicated towards the segmental allopolyploid nature in which $34.83 \%, 6.47 \%$ and $42-52 \%$ chromosomes were recorded to be involved in multivalent formation respectively. Resultant of which irregular chromosomes segregation during anaphases, abnormal sporad formation, unequal sized fertile pollen grains and also unstained/sterile pollen grains were observed.

\section{Cytomixis}

The phenomenon of cytomixis involving inter PMCs transfer of chromatin material had been reported to occur in 40 species (Table 2). The chromatin transfer in these species involving varying number of PMCs (2-28) takes place during all the stages of meiosis-I and II (Fig. 1i-m). Interestingly, the cytoplasmic channels showing chromatin transfer are also recorded among microspore units of sporads in Clematis orientalis var. acutifolia, Dianthus angulatus and Heracleum candicans (Fig. 1n-p). As a result of partial or complete chromatin transfer between meiocytes, hypo-, hyperploid and enucleated PMCs have been observed in majority of these species (Fig. 1q, r). In the present investigations, nucleolus also gets transferred along with the chromatin material from the donor PMC to the recipient PMC and the resultant PMC are depicted with two nucleoli as observed in Astragalus grahamianus, Salvia nubicola, Thalictrum cultratum, Trigonella pubescens, and Vicia pallida. All these taxa showed a variety of meiotic abnormalities included fragmentation and pycnosis of chromatin (Fig. 1s), interbivalent connections, irregular segregation of bivalents, aberrant microspores, and pollen sterility and heterogeneous sized fertile pollen grains in connection with this phenomenon of chromatin transfer.

\section{Chromosome stickiness}

The phenomenon of chromosome stickiness causing the chromosome aggulination or sticky appearance of chromosomes reported for the first time in maize [11] and 


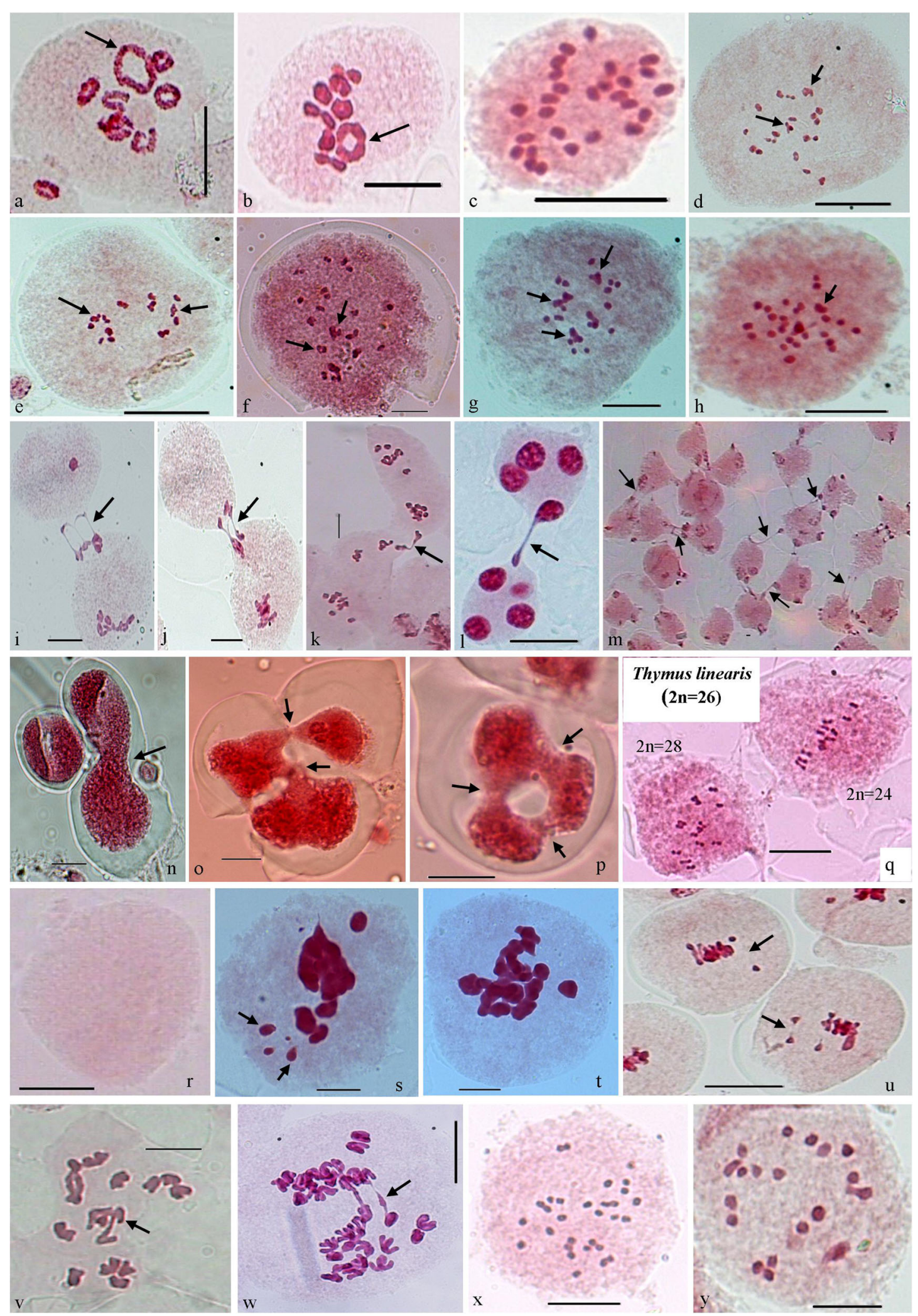

Fig. 1 (See legend on next page.) 
(See figure on previous page.)

Fig. 1 Various Meiotic deformities during meiosis. a) Achillea millefolium $(2 n=18)$; A PMC with $7 \Perp 1_{I V}$ (typical ring, arrowed) at diakinesis. b) $A$.

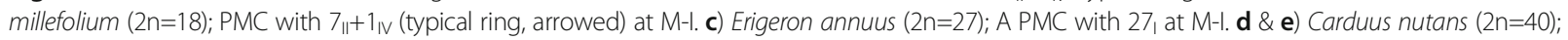
PMCs showed multivalents (arrowed) at M-I. f) Geranium pratense ( $2 n=56)$; PMC with multivalents (arrowed) at M-I. $\mathbf{g} \& \mathbf{h}$ ) Taraxacum officinale ( $2 n=32) ;$ PMCs showed multivalents (arrowed) at M-I. i) Two PMCs involved in chromatin transfer (arrowed) at P-I. j) Two PMCs involved in chromatin transfer (arrowed) at M-I. k) Two PMCs involved in chromatin transfer (arrowed) at A-I. I) Two PMCs involved in chromatin transfer (arrowed) at T-II. m) Group of PMCs involved in cytomixis (arrowed). n) Fusion of two monads. o) Intermicrosporal chromatin transfer among microspores of three tetrads. p) Cytoplasmic channels among microspores of a tetrad forming ring. q) Hypoploid ( $2 n=24)$ and Hyperploid $(2 n=28)$ PMCs in Thymus linearis (2n=26). $\mathbf{r}$ ) An enucleated PMC. s) A PMC at M-I showing pycnotic materials (arrowed). t) A PMC at M-I showing chromatin stickiness. u) Two PMCs at M-I showing early disjunction of bivalents (arrowed). v) A PMC at A-I showing late disjunction of chromosomes (arrowed). w) A PMC at A-I showing chromatin bridges (arrowed). $\mathbf{x}$ ) Dianthus angulatus ( $2 \mathrm{n}=30)$; A PMC with 30, at $\mathrm{M}-1$. $\mathbf{y})$ Inula cuspidata ( $2 \mathrm{n}=20$ ); A PMC with 20, at M-I

attributed it to a mutation caused by a recessive gene called sticky (st). Chromosome stickiness was presently scrutinized more frequently in the PMCs during M-I in Anemone rivularis $(n=8)$, Astragalus graveolens $(n=8)$, Berberis kunwarensis $(n=14)$, Clematis grata $(n=8), C$. graveolens $(n=8), C$. orientalis var. acutifolia $(n=16)$, Cuscuta reflexa $(n=16)$, Erigeron annuus $(2 n=27)$, Geranium pratense $(\mathrm{n}=28)$, Heracleum candicans $(n=11)$, Hippophae rhamnoides ( $n=9)$, Lotus corniculatus $(n=6)$, Myosoton aquaticum $(n=14)$, Nicotiana tabacum $(\mathrm{n}=24)$, Pedicularis bicornuta ( $n=8)$, Ranunculus laetus $(n=14)$, $R$. sceleratus $(n=16)$, Spergularia diandra $(n=18)$, Vicia pallida $(n=12)$ and Vicia rigidula $(n=12)$ (Fig. $1 \mathrm{t})$. In these species, the severe chromatin stickiness enhanced the formation of pycnotic nuclei and delayed separation of bivalents at A-I/II, laggards and chromatin bridges, micronuclei, and ultimately resulted into sterile pollen grains.

\section{Nonsynchronous disjunction}

Nonsynchronous disjunction of bivalents (early and late) is either found in hybrid taxa or the species having different sized chromosomes and rate of chiasma terminalization $[12,13]$ or associated with other meiotic abnormalities [14]. Some of the presently studied species showed either precocious disjunction (Ranunculus laetus, $n=14$; Impatiens brachycentra, $n=7$; Chaerophyllum villosum, $n=11$; Aster molliusculus, $n=9$; Cosmos bipinnatus, $n=12$; Crepis multicaulis, $n=5$; Salvia nubicola, $n=8$ ) (Fig. $1 \mathrm{u}$ ) or late disjunction (Clematis graveolens, $n=8$; $C$. orientalis var. acutifolia, $n=16$; Delphinium roylei, $n=8$; Papaver dubium, $n=14$; Trigonella pubescens, $n=8$; Vicia pallida, $n=12 ; V$. rigidula, $n=12 ; V$. sativa, $n=6 ; V$. tenera, $n=7$; Anaphalis virgata, $n=14$; Crepis sancta, $n=5$; Erigeron acer, $n=9$; Inula cuspidata, $n=10$; Lactuca orientalis, $n=9$; Youngia glauca, $n=8$; Cuscuta reflexa, $n=16$; Physalis minima, $n=24 ;$ Leptorhabdos benthamiana, $n=7$; Pedicularis bicornuta, $n=8$; Hippophae rhamnoides, $n=9$ ) (Fig. $1 \mathrm{v}, \mathrm{w}$ ) of some bivalents. On the other hand, Ranunculus sceleratus, $n=16$; Thalictrum cultratum, $n=21$; Berberis kunwarensis, $n=14$; Inula cappa, $n=10$; and Senecio krascheninnicovi, $n=10$ showed both early and late disjunction of 1-2 bivalents.

Early disjunction of bivalents normally does not affect the normal distribution of chromosomes at A-I. While the late disjuction of bivalents in Ranunculus sceleratus, Papaver dubium, Vicia rigidula, V. sativa, Erigeron acer, Inula cappa, I. cuspidata, Lactuca orientalis, Youngia glauca, Cuscuta reflexa and Physalis minima causes lagging of chromosomes, chromatin bridges and consequently reduced pollen fertility $[4,15,16]$.

In Delphinium roylei, Vicia pallida, V. sativa, Inula cappa, I. cuspidata, Cuscuta reflexa, Lactuca orientalis and Youngia glauca, larger sized bivalents scrutinized with decelerated segregation at A-I/II. In Delphinium roylei, Vicia sativa, and Cuscuta reflexa, this abnormality does not seem to affect the pollen fertility but in Vicia pallida, Inula cappa, I. cuspidata, Lactuca orientalis and Youngia glauca, late disjunction have resulted in the presence of laggards which may originate micronuclei at telophase-I/II and leading to reduced pollen fertility.

\section{Asynaptic mutants}

The lack of chromosome pairing and inability to generate or retain chiasmata during P-I led to asynaptic and desynaptic mutant formation. In Dianthus angulatus $(2 \mathrm{n}=30)$ (Fig. 1x) and Inula cuspidata $(2 \mathrm{n}=20)$ (Fig. 1y), chromosomes remain unpaired as univalents which disorganized into more than standardized number of chromatin poles during segregation of chromosomes at A-I/ II. A high frequency of aberrant microspores including monads, dyads, triads, tetrads with micronuclei and polyads, sterile gametes and heterogeneous sized pollen grains are the major consequences.

\section{Syncyte PMCs}

The fusion of two or more meiocytes presently scrutinized in Clematis graveolens $(2 \mathrm{n}=16)$ (Fig. 2a) and Dianthus angulatus $(2 \mathrm{n}=30)$ during the early stages of meiosis-I. However the occurrence of these synmeiocyte was found to be at very low frequency. These PMCs with double content of genome undergo the meiosis and led to the formation of polyploid gametes. In both cases, the 
Table 2 Consolidated data on cytomixis in the presently studied species

\begin{tabular}{|c|c|c|c|c|c|c|c|c|c|}
\hline S.No. & Taxa & $\begin{array}{l}\text { Meiotic } \\
\text { chromosome } \\
\text { number (n) }\end{array}$ & $\begin{array}{l}\text { Ploidy } \\
\text { level }\end{array}$ & $\begin{array}{l}\% \text { age of PMCs } \\
\text { with cytomixis }\end{array}$ & $\begin{array}{l}\text { No. of PMCs } \\
\text { involved in cytomixis }\end{array}$ & $\begin{array}{l}\text { Meiotic } \\
\text { stages }\end{array}$ & $\begin{array}{l}\text { Meiotic } \\
\text { course }\end{array}$ & $\begin{array}{l}\text { Pollen } \\
\text { fertility } \\
\text { \%age }\end{array}$ & $\begin{array}{l}\text { Pollen } \\
\text { size }\end{array}$ \\
\hline 1. & Anemone rivularis & 8 & $2 x$ & 1.28 & 2 & $\mathrm{Al} / \mathrm{II}, \mathrm{Tl} / \mathrm{II}$ & Abnormal & 94 & Uniform \\
\hline 2. & Aquilegia fragrans & 7 & $2 x$ & 4.2 & $2-3$ & $\mathrm{EPI}, \mathrm{Ml}$ & Normal & 99 & Uniform \\
\hline 3. & Astragalus grahamianus & 8 & $2 x$ & 71.27 & 2-group & MI-TII & Abnormal & 92 & Uniform \\
\hline 4. & A. graveolens & 8 & $2 x$ & $17.02-20.55$ & 2 & $\mathrm{Pl}-\mathrm{Tl}$ & Abnormal & $96-97$ & Variable \\
\hline 5. & Calamintha clinopodium & 10 & $2 x$ & 7.20 & 2 & $\mathrm{Ml}, \mathrm{Tl}$ & Abnormal & 99 & Uniform \\
\hline 6. & $\begin{array}{l}\text { Chaerophyllum } \\
\text { acuminatum }\end{array}$ & 11 & $2 x$ & 17.44 & $2-6$ & $\mathrm{Al}-\mathrm{TI}$ & Abnormal & 96 & Uniform \\
\hline 7. & Clematis grata & 8 & $2 x$ & 3.68 & $2-3$ & $\mathrm{Al}, \mathrm{Tl}$ & Abnormal & $88-98$ & Uniform \\
\hline 8. & C. graveolens & 8 & $2 x$ & $0.56-66.67$ & $2-28$ & $\mathrm{PI}-\mathrm{TII}$ & Abnormal & $91-98$ & Variable \\
\hline 9. & C. orientalis var. acutifolia & 16 & $4 x$ & $9.33-29.80$ & $2-3$ & $\begin{array}{l}\text { EPI- } \\
\text { Tetrad }\end{array}$ & Abnormal & $84-94$ & Variable \\
\hline 10. & Crepis multicaulis & 5 & $2 x$ & $7.67-11.10$ & $2-10$ & PI-Al & Abnormal & $92-96$ & Uniform \\
\hline 11. & Cynoglossum zeylanicum & 12 & $2 x$ & 1.56 & 2 & $A-I$ & Abnormal & 92 & Uniform \\
\hline 12. & Dianthus angulatus & $2 n=30$ & $2 x$ & 14.65 & $2-4$ & $\begin{array}{l}\text { Ml- } \\
\text { Tetrad }\end{array}$ & Abnormal & $58-62$ & Variable \\
\hline 13. & Eriocycla caespitosa & 11 & $2 x$ & 1.88 & $2-3$ & $\mathrm{PI}-\mathrm{TII}$ & Abnormal & 97 & Uniform \\
\hline 14. & Fragaria nubicola & 7 & $2 x$ & 17.45 & $2-8$ & Ml-Al & Normal & 95 & Uniform \\
\hline 15. & Heracleum candicans & 11 & $2 x$ & 26.53 & 2 & $\begin{array}{l}\text { EPI- } \\
\text { Tetrad }\end{array}$ & Abnormal & $95-96$ & Variable \\
\hline 16. & Hippophae rhamnoides & 9 & $2 x$ & $7.95-43.90$ & $2-4$ & EPI-TI & Abnormal & $93-99$ & Variable \\
\hline 17. & Indigofera heterantha & 24 & $6 x$ & $21.11-26.00$ & $2-3$ & EPI-TI & Normal & $98-99$ & Uniform \\
\hline 18. & $\begin{array}{l}\text { Leptorhabdos } \\
\text { benthamiana }\end{array}$ & 7 & $2 x$ & 9.45 & 2 & $\mathrm{Ml}$ & Abnormal & 96 & Variable \\
\hline 19. & Lotus corniculatus & 6 & $2 x$ & 18.34 & $2-3$ & $\mathrm{PI}-\mathrm{TII}$ & Abnormal & 88 & Uniform \\
\hline 20. & Medicago falcata & 8 & $2 x$ & $15.43-52.11$ & $2-4$ & EPI-MI & Abnormal & 89-92 & Uniform \\
\hline 21. & Melilotus alba & 8 & $2 x$ & 8.67 & $2-3$ & EPI-MI & Abnormal & $95-96$ & Uniform \\
\hline 22. & Mentha longifolia & 12 & $2 x$ & 2.67 & $2-5$ & Ml & Normal & 99 & Uniform \\
\hline 23. & Nepeta erecta & 9 & $2 x$ & $8.11-14.17$ & 2-group & EPI & Abnormal & $92-98$ & Uniform \\
\hline 24. & Nicotiana tabacum & 24 & $4 x$ & 22.80 & $2-3$ & EPI-MI & Abnormal & 87 & Uniform \\
\hline 25. & Pedicularis bicornuta & 8 & $2 x$ & $11.93-31.63$ & 2 & Ml-TI & Abnormal & $96-97$ & Variable \\
\hline 26. & $\begin{array}{l}\text { Potentilla atrisanguinea } \\
\text { var. atrisanguinea }\end{array}$ & 28 & $8 x$ & 38.56 & $2-5$ & EPI & Abnormal & $94-96$ & Variable \\
\hline 27. & Ranunculus laetus & 14 & $4 x$ & $22.51-24.05$ & $2-4$ & EPI-MI & Abnormal & $89-90$ & Variable \\
\hline 28. & Salvia nubicola & 8 & $2 x$ & $26.02-30.88$ & $2-4$ & EPI-MI & Abnormal & $96-97$ & Uniform \\
\hline 29. & Senecio krascheninnicovi & 10 & $4 x$ & 18.29 & $2-11$ & MI-TI & Abnormal & 96 & Variable \\
\hline 30. & Silene edgeworthii & 12 & $2 x$ & 13.87 & $2-3$ & $\mathrm{Al}-\mathrm{TI}$ & Abnormal & 83 & Variable \\
\hline 31. & Spergularia diandra & 18 & $4 x$ & 2.87 & 2 & $\mathrm{Ml}, \mathrm{TI}$ & Abnormal & 92 & Uniform \\
\hline 32. & Thalictrum cultratum & 21 & $6 x$ & 47 & $2-3$ & EPI-MI & Abnormal & $91-94$ & Variable \\
\hline 33. & T. foetidum & 21 & $6 x$ & $1.70-43.20$ & $2-6$ & EPI-TII & Abnormal & $78-98$ & Variable \\
\hline 34. & T. minus & 7 & $2 x$ & 2.04 & $2-3$ & EPI-MI & Normal & 98 & Uniform \\
\hline 35. & Thymus linearis & 13 & $2 x$ & 26.45 & $2-3$ & MI-TI & Abnormal & 93 & Variable \\
\hline 36. & Trifolium repens & 16 & $4 x$ & $5.34-6.02$ & $2-4$ & $\mathrm{Ml}, \mathrm{Al}$ & Normal & $90-91$ & Uniform \\
\hline 37. & Trigonella emodi & 8 & $2 x$ & $15.88-17.24$ & $2-3$ & EPI-AI & Abnormal & $93-94$ & Variable \\
\hline 38. & T. pubescens & 8 & $2 x$ & $47.05-62.88$ & 2-group & EPI-TII & Abnormal & $38-54$ & Variable \\
\hline 39. & Vicia pallida & 12 & $4 x$ & $1.52-2.20$ & $2-3$ & $\mathrm{Al} / \mathrm{II}, \mathrm{TI}$ & Abnormal & 83-89 & Variable \\
\hline 40. & V. rigidula & 12 & $4 x$ & 6.52 & $2-3$ & $\mathrm{EPI}, \mathrm{TI}$ & Abnormal & $80-81$ & Variable \\
\hline
\end{tabular}




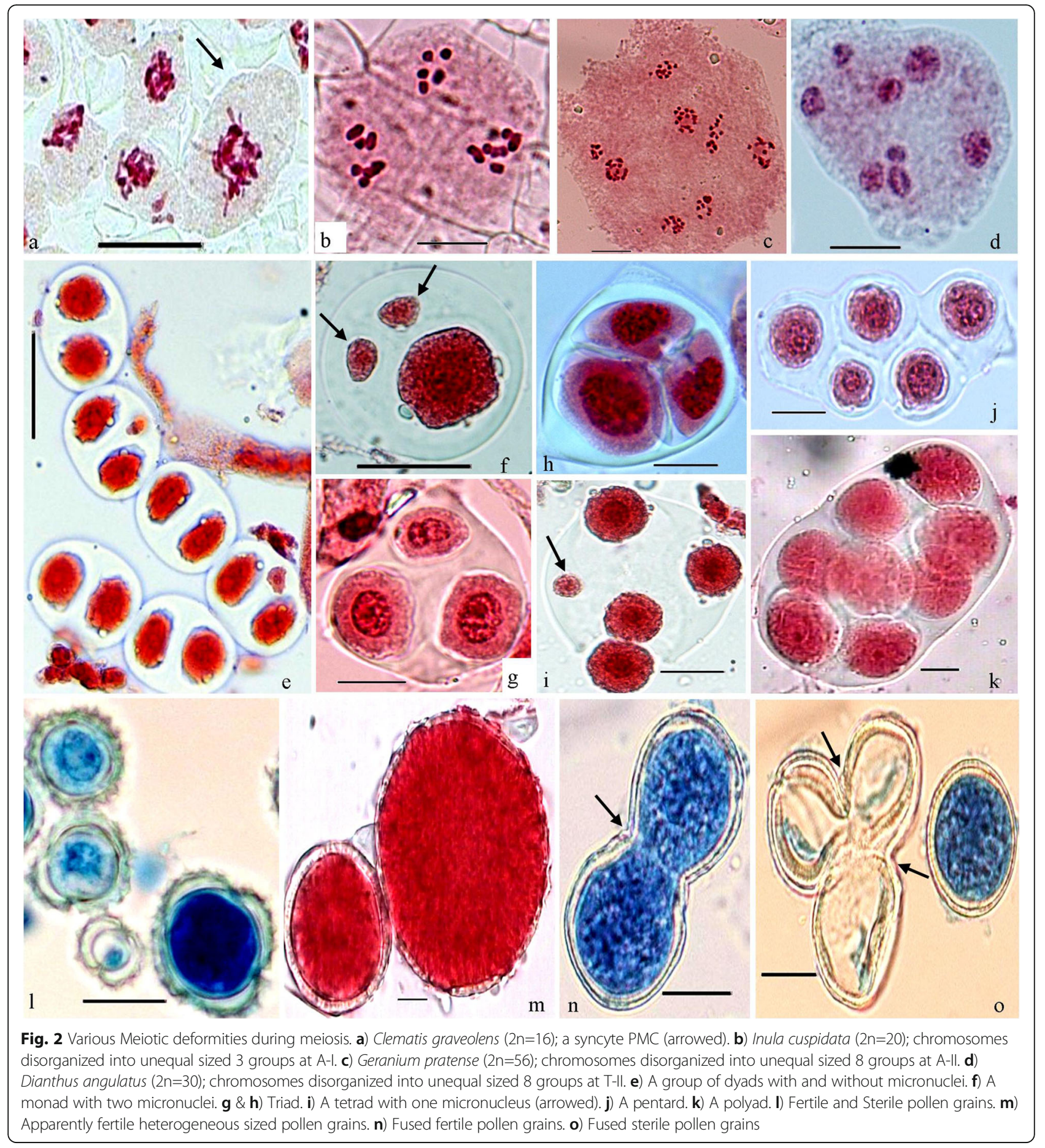

male gametes are larger in size and well fertile and able to fertilize the female gamete and might play significant role in the origin of intraspecific polyploids.

\section{Abnormal spindle}

Spindle organization were found to be abnormal during meiosis in Colutea nepalensis $(2 \mathrm{n}=16)$, Dianthus angulatus $(2 \mathrm{n}=30)$, Erigeron annuus $(2 \mathrm{n}=27)$, Geranium pratense $(2 \mathrm{n}=56)$, Inula cuspidata $(2 \mathrm{n}=20)$, Papaver dubium $(2 \mathrm{n}=28)$ and Taraxacum officinale $(2 \mathrm{n}=32)$. Here, the chromosomes fail to assemble on the spindle fibres during metaphases which is the essential property for their synchronous segregation, so they finally congregate into disparate sized chromatin nuclei at anaphases and telophases (Fig. 2b-d). As a consequence, abnormal microspores (Fig. 2e-k) are resulted which lead to low pollen 
fertility (Fig. 2l) and pollen grains of heterogeneous sizes (Fig. 2m).

\section{Fused Pollen grains}

Fusion among 2-3 pollen grains resulting into large sized pollen grains have been observed in Clematis graveolens $(n=8)$ (Fig. 2n, o). In this species, 2-3 pollen grains are fused by forming cytoplasmic channels.

\section{Discussion}

Analysis of meiotic chromosome associations in diploid and polyploid plants can give precise knowledge of chromosome homology and synapsis during meiosis [17]. Inter/intraspecific hybrid origin of a plant might contemplate the level of chromosome homology. Structural heterozygosity for reciprocal translocation arguably denote the configuration of typically ring, zigzags and chains of four chromosomes in Achillea millefolium $(n=9 ; 2 x)$. Further, persistence of multivalents is also determined by the presence of homologous gene sequences and keep possession of chiasma in multiple associated chromosomes. Occurrence of univalents and multivalents in complex and instable polyploid genome of Erigeron annuus $(2 \mathrm{n}=27 ; 3 \mathrm{x})$, Carduus nutans $(2 \mathrm{n}=40$; $4 \mathrm{x})$, Geranium pratense $(2 \mathrm{n}=56 ; 4 \mathrm{x})$, and Taraxacum officinale $(2 \mathrm{n}=32 ; 4 \mathrm{x})$ with distorted behaviour during gamete formation led to low reproductive success. Such chromosomal associations occur in nature at a low rate, may arise spontaneously or induced by a variety of factors including chemical or irradiation treatments [18]. The inverse correlation between frequency of chromosome associations and pollen fertility also reported in Hyoscyamus muticus [19] and Brassica campestris var. toria [20].

Cytomixis, an evolutionary, panoramic, cytological phenomenon which is a possible cause of aneuploidy and polyploidy in species [7], and produce unreduced pollen grains as reported in Hordeum species [21], Dianthus angulatus [22], and Houttuynia cordata [23] Chlorophytum borivilianum [24]. Many workers have pointed of view that the reduction in pollen viability is due to cytomixis [23, 24]. Till date, there is no clear cut opinion regarding the origin and nature of the cytomixis. Some interpretation which are thought to be responsible for cytomixis include the action of chemical agents such as colchicines [25], the use of herbicides [26], physiological and environmental factors [27], stress factors and genetic control [28]. In presently studied taxa, genetic factors and pressure of stress environment conditions seems to be the originator of this phenomenon of cytomixis [28-30].

Chromosome stickiness co-occurred with cytomixis appear to be commenced the pycnosis and degeneration of chromatin material as earlier reported by other workers [22, 31-33]. Several workers have reported that chromosome stickiness may be either under genetic control [34] or due to improper folding of chromosome fibres [35], or may also have been caused by other factors such as X-rays [36] and low temperature [37]. The presence of aluminum in the soil, besides the genetic factor, may have also caused chromosome stickiness in maize [32].

It becomes necessary for all the chromosomes to get synchronously disjucted during anaphases for the genome stability in the species. Expeditious rate of chiasma terminalization and least genic homology caused early disjunction of bivalents. Delayed segregation in Delphinium roylei, Vicia pallida, V. sativa, Inula cappa, I. cuspidata, Cuscuta reflexa, Lactuca orientalis and Youngia glauca during anaphases was due to having large sized bivalents which has also been reported in Cyathocline purpurea and Blumea spp. [38]. High chiasma frequency and their slow terminalization in large sized chromosomes might be the reason for delayed segregation.

A crucial phenomenon, synapsis, during early prophase stages is essential for gene recombination and evolutionary traits in the taxa [5]. Synaptic mutant might be due to mutations in genes controlling the chromosome pairing process and inability to generate or retain chiasmata between homologous chromosomes [5]. Several researchers have been reported for its spontaneous origin [39] and influenced by many factors like temperature, humidity and chemicals [5]. Presently the individuals of Dianthus angulatus and Inula cuspidata were growing under same climatic conditions detected with and without synaptic mutation so this make seem likely that a particular another factor might be involved. A concept of interspecific origin or non homology between two genomes could be the reason for synaptic mutation among the presently investigated taxa. A high frequency of unpaired elements in the genome of these taxa led to sterile and $2 n$ fertile gamete formation in the end of meiosis as has also been reported in higher plants [39-41].

The spindle apparatus is normally bipolar and playing a crucial role in the accurate segregation of chromosomes during mitosis and meiosis [42]. Several mutants are known to cause failure of the spindle or impair disjunction mechanisms, like $d v, m s 28$ and $m s 43$ mutants as reported in maize [43]. Multipolar Spindle 1 (MPS1), a plant-specific protein which is involved in spindle organization in meiocytes has been identified in Arabidopsis thaliana [44]. Improperly aligned chromosomes on distorted spindle face either unequal or total failure of segregation during anaphases which might to be taken to lead into restitution nuclei or polyploidy or aneuploidy in resultant gametes.

Also this low temperature stress conditions prevailing in the presently investigated area might lead the 
amalgamation of PMCs and pollen grains. These syncyte PMCs have earlier recorded in Brachiaria jubata [45], Chrysanthemum [46], and Lindelofia longifolia var. falconeri [47]. The fusion of cell wall of pollen grains has also been recorded in intergeneric hybrids $[48,49]$. The origin of intraspecific polyploidy in these taxa cannot be changed in spite of the low frequency of such fused PMCs and pollen grains.

\section{Conclusions}

Production of unreduced $2 \mathrm{n}$ gametes (double sized pollen grains) are the major consequence of these meiotic abnormalities in these studied taxa. Further these $2 \mathrm{n}$ male gametes fertilize the female gamete of respective species and led to origin of polyploidy. These all presently detected in the plants growing under the natural conditions particularly freezing temperature prevailing in the area which leads to low sexual reproductive success. The adoption of vegetative mode of reproduction may be the better regeneration method in such plants.

\section{Methods}

\section{Collection and submission of samples}

Study materials were collected from Kinnaur district of Himachal Pradesh (India) during the months of April to September for five years (2007-2011).Voucher specimens of the cytologically worked out individuals were deposited in the Herbarium, Department of Botany, Punjabi University, Patiala (PUN).

\section{Cytological Analysis and Photomicrographs}

For cytological study, young floral buds of dicot plants were fixed in carnoy's fixative (6 ethanol: 3 chloroform: 1 acetic acid) and then stored at $4{ }^{\circ} \mathrm{C}$ in $70 \%$ alcohol. Standard squash method (1\% acetocarmine) was applied for observing all the meiotic stages clearly. Meiocytes, sporads and pollen grains were photomicrographed from the freshly prepared slides using Leica Qwin Digital Imaging System and Nikon Eclipse $80 i$ microscope at laboratories situated in Department of Botany, Punjabi University, Patiala.

\section{Abbreviations}

A-I/II: Anaphase-I/II; M-I/II: Metaphase-I/II; P-I/II: Prophase-I/II; PMC: Pollen Mother Cell; T-I/II: Telophase-I/II

\section{Acknowledgements}

The authors are thankful to Head, Department of Botany, Punjabi University, Patiala (India) for providing necessary laboratories, herbarium and library facilities. The author also extends thank to Patel Memorial National College, Rajpura (Punjab) India for providing internet facility.

\section{Funding}

No funding was obtained for this study.

\section{Authors' contributions}

DK collected the sample, performed the experiment, analyzed the data, and interpreted the results. VKS designed the experiment. DK drafted the manuscript. DK and VK reviewed and edited the manuscript. All authors read and approved the final manuscript.

Ethics approval and consent to participate

Not applicable.

\section{Consent for publication}

Not applicable.

\section{Competing interests}

The authors declare that they have no competing interests.

\section{Publisher's Note}

Springer Nature remains neutral with regard to jurisdictional claims in published maps and institutional affiliations.

\section{Author details}

${ }^{1}$ Department of Botany, Patel Memorial National College, Rajpura affiliated to Punjabi University, Patiala, Punjab, India. ${ }^{2}$ Department of Botany, Punjabi University, Patiala, Punjab, India.

Received: 27 June 2018 Accepted: 7 December 2018

Published online: 07 January 2019

\section{References}

1. Farmer JB, Moore JES. On the meiotic phase (reduction divisions) in animals and plants. Quart J Microscop Sci. 1905;48:489-557.

2. Wendel JF. Genome evolution in polyploids. Plant Mol Biol. 2000;42:225-49.

3. Pagliarini MS. Meiotic behavior of economically important plant species: the relationship between fertility and male sterility. Genet Mol Biol. 2000;23:997-1002.

4. Jiang Y, Ding C, Yue H, Yang R. Meiotic behavior and pollen fertility of five species in the genus Epimedium. Afr J Biotechnol. 2011;10:16189-92.

5. Koduru PRK, Rao KM. Cytogenetics of synaptic mutants in higher plants. Theor Appl Genet. 1981;59:197-214.

6. Hamant O, Ma H, Cande WZ. Genetics of meiotic prophase-I in plants. Annu Rev Plant Biol. 2006;57:267-302.

7. Lattoo SK, Khan S, Bamotra S, Dhar AK. Cytomixis impairs meiosis and influences reproductive success in Chlorophytum comosum (Thunb.) Jacq. an additional strategy and possible implications. J Biosci. 2006;31:629-37.

8. Rezaei M, Arzani A, Sayed-Tabatabaei BE. Meiotic behaviour of tetraploid wheats (Triticum turgidum L.) and their synthetic hexaploid wheat derivates influenced by meiotic restitution and heat stress. J Genet. 2010;89:401-7.

9. Chandler JM, Chan J, Beard BH. Chromosomal differentiation among the annual Helianthus species. Syst Bot. 1986;11:354-71.

10. Aparicio A, Albaladejo RG. Microsporogenesis and meiotic abnormalities in the hybrid complex of Phlomis composite (Lamiaceae). Bot J Linn Soc. 2003; 143:79-85.

11. Beadle GW. A gene for sticky chromosomes in Zea mays. Zeitschr Ind Abst Vererbungsl. 1932;63:195-217.

12. Singhal VK. Cytomorphological studies on some members of Polypetalae from Northern and Central India. Ph.D. Thesis. Patiala: Department of Botany, Punjabi University; 1982.

13. Wen J, Zeng X-h, Pu Y-y, Qi L-p, Li Z-y, Tu J-x, Ma C-z, Shen J-x, Fu T-d. Meiotic nondisjunction in resynthesized Brassica napus and generation of aneuploids through microspore culture and their characterization. Euphytica. 2010;173:99-111.

14. Kumar $\mathrm{P}$, Singhal VK, Kaur D, Kaur S. Cytomixis and associated meiotic abnormalities affecting pollen fertility in Clematis orientalis. Biol Plant. 2010;54:181-4.

15. Roxas DMR, dela Vina AC, Remirez DA. Cytogenetics of Solanum melongena Linn., Solanum aethiopicum and their F1 hybrid. Philipp J Crop Sci. 1995;20:129-40.

16. Farooq U, Saggoo MIS. Cytomorphological investigations in Oxyria digyna Hill. from the Kashmir Himalaya, India. Tsitol Genet. 2014;48:42-8.

17. Sybenga J. Meiotic Configurations. Berlin: Springer-Verlag; 1975.

18. Tripathi RS, Kumar G. Meiotic analysis of two translocation heterozygotes in Lathyrus sativus L. Cytologia. 2009;74:89-93. 
19. Srivastava S, Lavania UC, Sybenga J. Genetic variation in meiotic behaviour and fertility in tetraploid Hyoscyamus muticus: correlation with diploid meiosis. Heredity. 1992;68:231-9.

20. Swaminathan MS, Sulbha K. Multivalent frequency and seed fertility in raw and evolved tetraploids of Brassica campestris var. toria. Mol Gen Genet. 1959;90:385-92. https://doi.org/10.1007/BF00888813.

21. Sheidai M, Jafari S, Nourmohammadi Z, Beheshti S. Cytomixis and unreduced pollen grain formation in six Hordeum species. Gene Conserve. 2010;9:40-50

22. Kumar P, Singhal VK, Kaur D. Impaired male meiosis due to irregular synapsis coupled with cytomixis in a new diploid cytotype of Dianthus angulatus (Caryophyllaceae) from Indian cold deserts. Folia Geobot. 2012;47: 59-68. https://doi.org/10.1007/s12224-011-9107-8.

23. Guan J-Z, Wang J-j, Cheng Z-h, Liu Y, Li Z-y. Cytomixis and meiotic abnormalities during microsporogenesis are responsible for male sterility and chromosome variations in Houttuynia cordata. Genet Mol Res. 2012:11:121-30.

24. Mandal GD, Nandi AK. Cytomixis with associated chromosomal anomalies and the reproduction of Chlorophytum borivilianum Santapau \& R.R. Fern, Taiwania. 2017;62:211-5. https://doi.org/10.6165/tai.2107.62.211.

25. Dwivedi NK, Ksikdar AK, Jolly MS, Susheelamma BN, Suryanarayana N. Induction of tetraploidy in colchicine-induced mutant of mulberry. I. Morphological and cytological studies in cultivar Kanva 2. Indian. J Genet. 1988:48:305-11.

26. Bobak M, Herich R. Cytomixis as a manifestation of pathological changes after the application of trifuraline. Nucleus. 1978;21:22-6.

27. Boldrini KR, Pagliarini MS. Cell fusion and cytomixis during microsporogenesis in Brachiaria humidicola (Poaceae). S Afr J Bot. 2006; 72:478-81.

28. Malallah GA, Attia TA. Cytomixis and its possible evolutionary role in a Kuwait population of Diplotaxis harra (Boraginaceae). Bot J Linn Soc. 2003; 143:169-75.

29. Singhal VK, Kaur D. Cytomixis inducing meiotic irregularities and pollen malformation in Clematis graveolens Lindley from the cold deserts of Kinnaur district of Himachal Pradesh, India. Cytologia. 2011;76:319-27.

30. Singhal VK, Kaur D. Cytomixis and associated abnormalities during male meiosis in a new tetraploid cytotype of Vicia pallida Turcz. Fabaceae. Cytologia. 2012;76:387-93.

31. Mary TN, Suvarnalatha B. Cytomixis and deviation of chromosome numbers in pollen mother cells of Gossypium species. J Indian Bot Soc. 1981;60:74.

32. Caetano-Pereira CM, Pagliarini MS, Brasil EM, Martins EN. Influence of aluminium in causing chromosome stickiness in maize microsporocytes. Maydica. 1995;40:325-30.

33. de Souza AM, Pagliarini MS. Spontaneous chromosome stickiness in canola. Nucleus. 1996;39:85-9.

34. Dewitte A, Eeckhaut T, Van Huylenbroeck J, Van Bockstaele E. Meiotic aberrations during 2n pollen formation in Begonia. Heredity. 2010;104: 215-23.

35. Mc Gill MS, Pathak S, Hsu TC. Effects of ethedium bromide on mitosis and chromosomes: A possible material basis for chromosome stickiness. Chromosoma. 1974:47:157-67.

36. Steffensen D. Effect of various cation imbalances on the frequency of X-ray induced chromosomal aberrations in Tradescantia. Genetics. 1956:42:239-52.

37. Eriksson G. Temperature response of pollen mother cells in Larix and its importance for pollen formation. Stud Forestalica Suec. 1968:63:121-32.

38. Gupta RC. Cytological investigations on some Indian Compositae. Ph.D. Thesis. Patiala: Department of Botany, Punjabi university; 1981.

39. Sharma SK, Bisht MS, Pandit MK. Synaptic mutation-driven male sterility in Panax sikkimensis Ban. (Araliaceae) from Eastern Himalaya, India. Plant Syst Evol. 2010;287:29-36

40. Bernardo Filho RA, Santos ACC, Souza FHD, Valls JFM, Pagliarini MS Complete asynapsis resulting in $2 \mathrm{n}$ pollen formation in Paspalum jesuiticum Parody (Poaceae). Genet Mol Res. 2014;13:255-61.

41. Wani AA, Bhat TA. Asynaptic and Desynaptic in plants, Chapter in book, Chromosome Structure and Aberrations; 2017. p. 127-40. https://doi.org/10. 1007/978-81-322-3673

42. Nirmala A, Rao PN. Genesis of chromosomal numerical mosaicism in higher plants. Nucleus. 1996:39:151-75.

43. Golubovskaya IN, Distanova EE. Mapping meigene ms43 by B-A translocation stocks. Genetica. 1986:22:1173-80.
44. Jiang H, Wang F-f, Wu Y-t, Zhou X, Huang X-y, Zhu J, Gao J-f, Dong R-b, Cao K-m, Yang Z-n. Multipolar Spindle 1 (MPS1), a novel coiled-coil protein of Arabidopsis thaliana, is required for meiotic spindle organization. Plant J. 2009:59:1001-10.

45. Mendes-Bonato AB, Risso-Pascotto C, Pagliarini MS, Valle CB. Normal microspore production after cell fusion in Brachiaria jubata (Gramineae). Genet Mol Biol. 2003;26:517-20.

46. Kim JS, Oginuma K, Tobe H. Syncyte formation in the microsporangium of Chrysanthemum (Asteraceae): a pathway to intraspecific polyploidy. J Plant Res. 2009;122:439-44.

47. Singhal VK, Rana PK, Kumar P. Syncytes during male meiosis resulting into ' $2 \mathrm{n}$ ' pollen grains formation in Lindefolia longiflora var. falconeri. J Syst Evol. 2011:49:406-10. https://doi.org/10.1111/j.1759-6831.2011.00144.x.

48. Sun G, Yen C, Yang J. Intermeiocyte connections and cytomixis in intergeneric hybrids II. Triticum aestivum $\times$ Psathyrostachys huashanica. Wheat Inform Serv. 1993;77:13-8.

49. Sun G, Yen C, Yang J. Intermeiocyte connections and cytomixis in intergeneric hybrids III. Roegneria tsukushiensis $\times$ Psathyrostachys huashanica. Wheat Inform Serv. 1994;79:24-7.
Ready to submit your research? Choose BMC and benefit from:

- fast, convenient online submission

- thorough peer review by experienced researchers in your field

- rapid publication on acceptance

- support for research data, including large and complex data types

- gold Open Access which fosters wider collaboration and increased citations

- maximum visibility for your research: over $100 \mathrm{M}$ website views per year

At $\mathrm{BMC}$, research is always in progress.

Learn more biomedcentral.com/submissions 